\title{
The Spiritual Self: Toward a Conceptualization of Spiritual Identity Development
}

Timothy B. Smith

Brigham Young University, tbs@byu.edu

Justin B. Poll

Brigham Young University

Follow this and additional works at: https://scholarsarchive.byu.edu/facpub

Part of the Christianity Commons, and the Counseling Psychology Commons

\section{Original Publication Citation}

Poll, J., \& Smith, T. B. (2003). The spiritual self: Toward a conceptualization of spiritual identity development. Journal of Psychology and Theology, 31, 129-142.

\section{BYU ScholarsArchive Citation}

Smith, Timothy B. and Poll, Justin B., "The Spiritual Self: Toward a Conceptualization of Spiritual Identity Development" (2003). Faculty Publications. 2020.

https://scholarsarchive.byu.edu/facpub/2020 


\title{
The SpIRITUAL Self:
}

\section{TOWARD A CONCEPTUALIZATION OF SPIRITUAL IDENTITY DeVELOPMENT}

\author{
JUSTIN B. POLL AND TIMOTHY B.SMITH \\ Brigham Young University
}

Both researchers and practitioners have demonstrated considerable interest in identity development, and positive personal identities have been associated with numerous positive mental health outcomes. However, major theories of identity development have neglected the salience of spiritual identity, even though the early work of William James placed this as a central component of personality. This article reviews four major theories of identity development (cognitive, psychodynamic, systems, and narrative) and suggests spiritual identity parallels to these theories. A tentative model of spiritual identity development is presented. Implications for therapy and future research concerning spiritual identity development are discussed.

That they should seek the Lord, if haply they might feel after him, and find him, though he be not far from every one of us: "For in him we live, and move, and have our being"; as certain also as your own poets have said, "For we are also his offspring" (Acts 17:27-28).

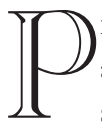
ofessional counselors and psychotherapists are demonstrating increasing interest in the spiritual lives of their clients, recognizing the importance of addressing spirituality in therapy (Miller, 1999; Richards \& Bergin, 1997; Schwartz, 1999). Furthermore, research indicates that mental health may be promoted through spiritual means (Bergin, 1991; Miller \& Martin, 1988; Richards \& Potts, 1995; Shafranske, 1996). In fact, some research suggests that certain clients may be effectively treated only when therapists respond to their spiritual and religious issues (Bergin, 1991; Kelly, 1995; Shafranske, 1996; Worthington, Kurusu, McCullough, \& Sanders, 1996).

Correspondence concerning this article may be sent to Justin B. Poll, PhD, Brigham Young University, MCKB, PO Box 25093, Provo, UT 84602-5093.
Recently, Miller (1999) issued a challenge to formulate a theory of spiritual identity development that particularly addresses how spiritual identity may be encouraged within therapy. This sense of spiritual identity, an individual's belief that she or he is an eternal being and connected to God, is an aspect of human spirituality thought to be effective in protecting and restoring psychological health (Richards \& Bergin, 1997). The supposed power of spiritual identity to promote resiliency and change in individuals corresponds with research indicating that similar benefits are derived from a strong sense of personal identity.

Previous research has shown that the health-promoting and health-restoring effects of a strong sense of identity are evident throughout the lifespan. In adolescents, healthy identity development may protect against depression (Koteskey, Little, \& Matthews, 1991) and encourage optimism and selfesteem (Roberts et al., 1999). Psychological wellbeing is also linked to healthy identity in adults (Pulkkinen \& Roenkae, 1994). Elderly individuals with healthy identities are able to maintain a sense of continuity in their lives and to deal effectively with age-related changes (Brandstadter \& Greve, 1994). According to Erikson (1950), successful identity development enables individuals to proceed more effectively with subsequent life tasks of intimacy, generativity, and integrity. Developing a sense of spiritual identity may also contribute to such desirable effects for individuals throughout their development. Through this article, we hope to respond to Miller's (1999) challenge by suggesting a spiritual identity development model and by providing implications of the model for psychotherapy and for future research. 


\section{TheORIES OF IDENTITy DeVELOPMENT: The Development of THE Spiritual SelF}

William James (1890, 1902, 1910/1968) provided an early yet enduring conceptualization of identity development. He posited that the study of one's identity involves considering two aspects of the self: the "I" and the "me." An individual's "I" functions consciously and objectively to create and connect the various "me's" and to maintain a sense of continuity of self across time. The types of "me" created by the "I" include the "material me," the "social me," and the "spiritual me." The "material me" consists of one's body, clothes, family, home, and collections. The "social me" involves how one is seen and responded to by others. The "spiritual me" is described as one's inner thinking and feeling self. James (1910/1968) referred to this "spiritual me" as "the true, the intimate, the ultimate, the permanent me which I seek" (p. 46). The spiritual me, or spiritual self, is further described as the "core" and "sanctuary of our life" (p. 43). It is the highest level of selforganization, more advanced than the "material me" and the "social me." Identity development, according to James, occurs as the "I" is driven to construct the multifarious "me's" and to organize these various selves around the central spiritual self.

Though James (1890) argued that experiencing the "spiritual me" may be understood as strictly psychological and physiological processes, he acknowledged the plausibility of more metaphysical explanations provided through the concept of the soul. Further, James submitted that understanding the nature of the knowing, creating, and connecting "I" may also require the idea of a soul. Others have argued that recognizing the reality of the soul is necessary to understand how the Jamesian "I" functions (Moreland, 1998).

Since the time that James proposed this early model of the self, identity development theorists have extended and modified his work; nevertheless, they have largely abandoned his emphasis on spiritual self-conceptualization. These later theorists have, therefore, overlooked the concept of the soul that James conceded may explain both the central, felt component of identity and the unifying agent of identity (Coon, 2000). Nevertheless, spiritual identity parallels may be drawn from post-Jamesian theories.

Major theories of identity development since James include psychodynamic, cognitive, systems, and narrative theories. Although other theories could also be addressed, this paper will focus on these four. With each theory, we will identify how the Jamesian "I" functions, what drives the "I," what "me's" are created, what developmental sequence is followed, and how healthy identity is achieved. We will then extend these theories to propose spiritual identity development parallels. Based on these parallels, we present a model of spiritual identity development informed by a theistic perspective of identity (Richards \& Bergin, 1997) that explicitly affirms the reality of the soul.

\section{Psychodynamic Theories}

Psychodynamic theories of identity development emphasize the process of individuals seeking to connect to and separate from others (Erikson, 1950; Mahler, Pine, \& Bergman, 1975). These theorists emphasize the Jamesian "social me," focusing on identity development through relationships, and deemphasize the Jamesian "I," suggesting a less conscious, more symbolic development of the self. This symbolic self develops through interactions with significant others, particularly interactions early in one's life. Children gain a sense of self as their significant others, their "self-objects," selectively confirm, or mirror, the images of themselves they display and communicate (Kohut, 1977).

From a psychodynamic perspective, the process of establishing an identity involves an individual sequencing through a period of being unaware of the self, to a period of recognizing and forming the self through interactions with primary others, and, finally, to a period of clearly perceiving the self in relation to others. Development is prompted by a period of intrapsychic crisis that challenges an aspect of identity or brings unconscious material into awareness (Erikson, 1950; Mahler, Pine, \& Bergman, 1975). Healthy identity is achieved, according to these theorists, as individuals gain a sense of self-constancy and other-constancy (Erikson, 1950; Mahler, Pine, \& Bergman, 1975), recognize and accept the strengths and weaknesses in themselves as well as in others (Kohut, 1977), and selectively internalize and reject beliefs and values (Erikson, 1950).

An implication of psychodynamic theories for spiritual identity development is that individuals may develop a sense of their spiritual selves in connection and continuity with God. Extending insights from psychodynamic theories, the Jamesian "I" may not function consciously; rather the "me" (Jamesian 
"spiritual me") representations may be derived implicitly through interactions with spiritual objects. According to Erikson (1996), the objects that shape the spiritual self include one's parents and one's God. Erikson purported that the parent-child relationship is "transferred" to a God-spiritual child relationship. He did not, however, explain how this occurs. Nevertheless, such a "transfer" has been suggested by Rizzuto (1979), who posited that individuals create their image of God from projected images of primary objects such as parents. If such projection occurs with one's conception of God's image, then a similar projection may take place with one's perceived relationship with God and, therefore, one's spiritual identity.

\section{Cognitive Theories}

Cognitive theorists conceptualize identity development as a meaning-making process. Like psychodynamic theorists, they emphasize the Jamesian "social me" and describe an individual's Jamesian "I" as organizing into meaningful self-schemas one's history of behaviors and input from others (Markus, 1977); differentiating the self from others, specifically the perspectives of others (Kegan, 1979); and creating ideal "possible selves" (Markus \& Nurius, 1986). The "I" is propelled to maintain equilibrium as it makes meaning of the outside world (Kegan, 1979) and of one's experiences (Markus, 1977), yet maintains a sense of organization, a sense of self.

Individuals' cognitive identities develop through sequential phases of lacking the ability to reflect upon and see the self objectively, to progressively gaining the ability to objectively perceive and direct the self, and, finally, to integrating an objective sense of the self and others. Development is prompted by conflicts stemming from schemas that are incongruent with the environment (Kegan, 1979). Healthy identity, according to the cognitive perspective, is attained by gaining greater objectivity in reflecting upon oneself and others (Kegan, 1979) and by being able to understand and direct one's life according to selfschemas (Markus, 1977; Markus \& Nurius, 1986).

Cognitive developmental theorists (Kegan, 1979; Markus, 1977) suggest that one's Jamesian "I" makes meaning of one's world, one's relation to the world, and one's experiences, giving coherence to the self. Extending insights from these theories would imply that an individual's "I" may also need to create a spiritual self, while developing spiritual schemas to orga- nize and give meaning to the world beyond, to her or his relation to the world beyond (i.e., God), and to her or his spiritual experiences. This proposed process is illustrated by research which suggests that spiritual schemas enable individuals to make sense of traumatic experiences outside their control, allowing them to separate themselves from these events by turning and connecting to God (Bjorck, 1995). From his research with children, Elkind (1997) posited that developing individuals have a "cognitive need capacity" to know that life has permanence, specifically that their lives have permanence (i.e., that they have eternal identities). He further proposed that religion provides answers to the question of permanence as well as fills subsequent "need capacities": needs to symbolize, to relate to, and to understand God. An individual's "I" may draw upon religious beliefs and spiritual experiences to satisfy these "need capacities," creating a "possible" eternal spiritual self-schema and a spiritual self-schema of one's separateness from and connection to God.

\section{Systems Theories}

Systems theorists (e.g., Bowen, 1978) assert that an individual's interpersonal contexts, one's systems, influence the developing self, specifically the developing Jamesian social self. Bowen (1978) purported that one's identity matures by "working out a 'self' in one's own family of origin" (p. 514). Bowen's Jamesian "I" separates, differentiates, and defines the self with reference to a system such as one's family. This self-system differentiation process is driven by the individual's desire to gain autonomy and distance from the emotional "entanglements" of one's system. The process is discouraged by systems that attempt to prevent such differentiation by involving the individual in emotionally enmeshing "triangles" with other members of the system (e.g., "undifferentiated ego mass" systems).

To develop a sense of identity, according to a systems perspective, an individual sequences from a phase of being emotionally fused or entangled with a system, to a phase of progressively detaching or disentangling from a system, and, finally, to a phase of sensing one's own distinctiveness and direct relatedness to others. Identity progression from fusion to detachment is prompted by stresses that challenge existing relationships within the system (Bowen, 1978). An individual who achieves a healthy sense of self, according to Bowen's model, is able to maintain 
objectivity within the system, to resist being easily influenced by other members of the system, and to establish healthy, intimate "person-to-person" relationships with others.

Within a systems theory framework (Bowen, 1978), the Jamesian "I" develops objectivity, or emotional distance, from systems such as one's family system or one's religious system, enabling an individual to achieve this healthy differentiation by turning and connecting to God (Richardson, 1987). This concept is supported by intrinsic/extrinsic religiosity research (Richards \& Bergin, 1997), which suggests that both spiritual health and mental health are encouraged by personal, genuine religious experience and are compromised by social, inauthentic religious practice. Perhaps the same connectedness-separateness balance between individuals and their systems is similarly healthy when applied to the individual's relationship with God. If individuals can connect to God while maintaining an objective sense of themselves, they may be able to relate more intimately to God and create a "person-to-God" relationship.

\section{Narrative Theories}

Narrative theories of identity development (McAdams, 1993, 1996) integrate psychodynamic, cognitive, and systems theories into a more complete conceptualization of the self. Narrative theorists propose that one's Jamesian "I" creates meaningful and coherent life stories, or self-stories. These self-stories allow individuals to see their lives as having continuity in time and connection to others and to ideas. The narrative "I" is motivated cognitively to find purpose and unity in life. Other "I" influences include one's early interactions (e.g., psychodynamic influences) and one's systems. The self-stories that are created include various self-symbols, selfschemas, and self-other-scripts.

Development of narrative identity has been suggested as following a sequence of "eras" (McAdams, 1996) in which a developing individual first experiences life without forming a self-story ("prenarrative era"), then creates a self-story from life experiences ("narrative era"), and finally reviews the created selfstory for a sense of meaning and completeness ("postnarrative era"). Development is prompted by a period of crisis in which a deficit in a current identity story is modified to provide a more meaningful and coherent narrative that unifies life experiences. From the perspective of narrative theory, individuals achieve a healthy identity as they develop a coherent life story that integrates their various self-stories into a meaningful whole (McAdams, 1993, 1996).

Just as narrative theory of identity development (McAdams, 1993, 1996) provides a useful model for integrating the other theories, the narrative perspective encapsulates the spiritual self within spiritual self-stories that include symbols, schemas, and scripts. Robertson (1990) proposed that individuals achieve spiritual identities by linking their life stories to the narratives of a religious community system and to their ongoing stories of personal revelation from God. These spiritual narratives may give individuals a sense of life continuity through eternal life stories and of connection to God through spiritual self-to-God story themes. One's sense of a storied spiritual self may develop through interactions with God that may be partially unconscious and symbolic and partially conscious and schematized.

\section{Summary of Insights from \\ Psychological Theories}

Although William James (1890, 1902, 1910/1968) proposed that spirituality is central to an individual's identity development, later theories of identity development have ignored or denied spiritual aspects of identity. Having reviewed four of these theories, we have extracted several common themes in an attempt to formulate the basis of a tentative theory that (re)affirms the construct of spiritual identity development. General insights synthesized across these theories include the following: (a) Individuals seek a sense of self that is connected to and separate from others with whom they interact; (b) individuals seek a sense of continuity and constancy in how they view themselves; and (c) individuals seek to organize and understand themselves in relation to others and to their experiences. These assumptions influence our conceptualization of spiritual identity development as a process that involves individuals' connection to and separation from God, perceptions of consistent spiritual themes across time and across situations, and spiritual experiences that provide meaning and purpose in their lives.

Moreover, each of the theories reviewed above specifies a general developmental sequence of identity development. Synthesis of these theories reveals at least four unique phases or stages of identity development: (a) a stage of being unaware of one's self as distinct yet connected to others; (b) a stage of learn- 
ing, crisis, or conflict that challenges unawareness of the self; (c) a stage of progressively experiencing and creating the self in relation to the world and to others; and, finally, (d) a stage of integrating experiences into a clear sense of self and others that provides meaning, coherence, and continuity. We draw upon this general developmental sequence in formulating our model of spiritual identity development.

\section{A Theistic Perspective of SPIRITUAl IDENTITy DeVElopment}

In the process of gleaning insights for spiritual identity development from these four post-Jamesian psychological theories, we openly acknowledge making certain assumptions about spirituality, some of which were made explicit by James (1890, 1910/1968) in his discussion of the soul. Specifically, we assume the reality of the soul; humans are spiritual beings. Our conceptualization of spiritual identity is therefore similar to the theistic model of human development proposed by Richards and Bergin (1997). Grounded in the teachings of predominant world religious and spiritual traditions, Richards and Bergin's theistic model makes explicit assumptions about spiritual reality: God exists, human beings are children of God, humans possess temporal physical bodies and eternal spirits, humans are able to communicate with God through spiritual means, and humans are able to recognize/remember their true nature as eternal beings of divine potential. These assumptions clearly distinguish spiritual identity development from other forms of social or emotional development, and they are central to the synthesis of perspectives we propose here. Put simply, we affirm that without faith that God exists and that humans are in fact spiritual in nature, the concept of spiritual identity has little merit, being merely a different aspect of social identity. The validity of a model of spiritual identity development therefore depends on the veracity of theistic assumptions, which are ignored or denied by other conceptualizations of identity.

\section{A Model for Spiritual Identity Development}

By integrating the insights from psychological theories with the theistic assumptions articulated by Richards and Bergin (1997), a model for spiritual identity can be formulated. This proposed model is based on the reality that we are the "offspring of God" (Acts 17:28), specifically that God is the
"Father of [our] spirits" (Hebrews 12:9). It is through our spirits that God communicates with us (Romans $8: 16)$. Others have noted that in addition to providing spiritual receptivity, our spirits or souls enable other faculties such as thinking and feeling (Moreland, 1998). Through such spiritual faculties, individuals can both experience their developing spiritual lives and reflect upon this development to construct a sense of spiritual identity.

The part of us that experiences spiritual development may be referred to as the Jamesian "spiritual me," whereas the part of us that reflects upon and organizes such experiences into a sense of spiritual identity may be referred to as the Jamesian "I." The separation here into the experiencing self and the constructing self is done for explanatory purposes rather than to suggest that these are distinct parts of the self. We, like others (Sauvayre, 1995), contend that the self is an integration of the experiencing object and the constructing subject; the spiritual self develops through the interplay of spiritual experiences and spiritual self-constructions.

In our proposed model, individuals develop a sense of spiritual self in relation to God by interacting with God and by recognizing divine within themselves and others. Such interactions and recognitions can be termed "spiritual experiences" or, as expressed by James (1902), "mystical experiences."

We assert that individuals are intrinsically motivated to "feel after" (Acts 17:27) a relationship with God. Recognition of spiritual experiences increases that motivation. Moreover, by reflecting upon spiritual experiences from the past and by projecting such experiences into the future through faith, individuals are able to feel continuity and constancy of their spiritual selves as eternal beings. Internalization of spiritual experiences allows individuals to construct a sense of a spiritual self in relation to the world in which they live and to the world beyond.

Stages of spiritual identity development. A developmental sequence for this model of spiritual identity development can be proposed by integrating insights from the discussed identity theories with theistic insights. The first phase or stage of the developing spiritual self would be Pre-awareness of the self as an eternal being in relation to God. At this point, individuals do not consciously regard themselves in spiritual terms. Either they have not had experiences identified as spiritual or else the salience of past spiritual experiences has been minimized or forgotten. 
The second stage usually involves a period of learning, crisis, or conflict that prompts an Awakening of awareness of the self in relation to God. Although a single major crisis may raise awareness in and of itself, more often the spiritual learning or conflict will be generated by a series of several events recognized as related that are of sufficient intensity to prompt awareness. Individuals at this stage begin to recognize events or interactions in spiritual terms. Although this recognition may at times be emotionally intense, the quality of spiritual awareness will tend to be inconsistent, fragmented, or specific to the crisis/situation at hand (e.g., a child only thinking of God when attending church or as an adult rarely thinking of God except when blaming Him for the premature death of a spouse).

The third stage would entail Recognition and recollection of other spiritual experiences, such that the initial awareness obtained in the previous stage is progressively generalized to an awareness of spiritual experiences in other settings and interactions. Individuals at this stage begin to develop a consistent spiritual identity by having more spiritual experiences and by reflecting upon similar experiences in the past. Thus, spiritual themes begin to emerge for the individual, although these themes may be predominantly cognitive or emotional (e.g., individuals who accept the doctrine of a particular religious sect or who on occasions feel moved by spiritual messages but who otherwise primarily see themselves in terms of their material/social attributes and experiences).

The fourth, and final, stage of this model involves an Integration of spiritual experiences with self-concept. Spiritual experiences typically seen in previous stages as external to the person become internalized, simultaneous with the development of spiritual relationships, person to person and person to God. Individuals at this stage recognize their own spiritual nature, and they perceive and interact with the world accordingly. More accurately stated, individuals at this stage begin to interact and relate with God and with others in spiritual terms, such that they come to see themselves as spiritual beings through the consistent interaction. Themes of spirituality are woven throughout many aspects of their life because they recognize spiritual experiences across many settings. They spontaneously take in and seek out spiritual experiences because doing so has become for them a way of life.

Individual differences in spiritual identity. In proposing this model of spiritual identity develop- ment, we recognize that individuals vary greatly in how they describe spirituality and how they experience a relationship with God. The content of a spiritual identity is highly idiosyncratic, depending largely on the religious orientation, personality characteristics, and previous spiritual experiences of the person.

This idiosyncrasy of spiritual identity should not be surprising, given that psychological identities are also fluid and highly unique (e.g., James, 1890, 1910/1968). The psychological theories reviewed previously have all indicated that individuals seek to understand themselves in relation to others and to their experiences, factors which vary dramatically from person to person. Individuals form their identity based on their own unique history and beliefs about who they are and who they should become over time. Paralleling this process, we suggest that individuals will strive to develop a spiritual identity that corresponds with what they believe God to be. The developmental sequence from Preawareness to Integration will, therefore, progress in accordance with an individual's beliefs about God or his or her God image (e.g., Hood, 1989; Rizzuto, 1979; Stark, 2000) as they come to match their beliefs more and more with God's true attributes. That is, although individuals initially (Pre-awareness to Recognition) tend to create themselves in the image of their God or god, which may often be projections constructed through early interactions with primary caregivers (e.g., Rizzuto, 1979), the entire process of spiritual identity development is one of unlearning beliefs about God based on interactions with others and refining more accurate images of the true attributes of God by interacting directly with Him. Thus, although individuals widely differ in their current perceptions of God due to their previous experiences, our model affirms that spiritual experiences reveal God to the individual, and the more individuals come to know God, the more they see themselves as His children, created in His Image (Genesis 1:26; 1 Corinthians 13:12). This assertion is developed more below.

Psychological identity develops as individuals selectively internalize and reject beliefs and values to more accurately match their own experiences and circumstances (e.g., Erikson, 1950), with mental health partially being a function of how well their identity matches reality. A parallel process may occur with spiritual identity development. Specifically, we suggest that spiritual identity development will progress or digress in accordance with how accurate- 
ly an individual's God image corresponds with his or her environment and, more importantly, with his or her own behaviors and spiritual experiences. For example, persons who believe that God unconditionally loves all people and aspire themselves to love others as best they can, may, with sufficient repetition, establish a pattern of spontaneous charitable behavior and thereby internalize a degree of their God image, leading to positive gains in self-concept and mental health. Conversely, persons who become highly critical of those who take advantage of their kindness may find it difficult to progress past a Recognition stage of identity because the aspired value is not internalized. In accordance with psychological principles (e.g., Erikson, 1950; McAdams, 1996), a person's optimal aspired identity should be (a) personally relevant, (b) beneficial, and (c) acknowledged and reciprocated by others. Therefore, spiritual identity will develop best when individuals' image of God is relevant to their own lives, benevolent and meaningful, and ultimately reciprocated through a relationship with God. Oppositely, spiritual identity development will be restricted to the degree that individuals perceive God as detached, punitive, judgmental, etc., which attributes are characteristic projections of childhood interactions with primary caregivers (Rizutto, 1979).

As indicated earlier, psychological theories also suggest that identity progresses as some values are refined or rejected through detachment or differentiation (e.g., Bowen, 1978; Kegan, 1979). To draw another parallel with spiritual identity development, when a person's God image consistently conflicts with her or his environment or behavior, the person may refine or modify her or his God image. For example, the person who has become critical of others could modify the belief that God unconditionally loves all people to a belief that God loves all people but also judges and rewards them differently based on the talents/attributes given them. This changed belief structure would allow the person to refrain from criticizing others by either (a) only being kind to those the person feels deserve to be rewarded by God, or (b) recognizing that God is the only judge and, therefore, she or he should seek God's grace and attempt to "turn the other cheek." Although these two modifications could both have the effect of reducing the person's overt criticisms, thereby increasing his or her behavioral congruence with his or her God image, the outcomes clearly differ in terms of external standards, principally the teachings of the Bible (Luke 6:27-35). We therefore assert that the more accurately a person's beliefs about God reflect God's true attributes, the more developed (consistent, meaningful) that person's spiritual identity will be.

In sum, just as individuals' psychological identity and well-being increase as their identity more accurately matches their own behavior and their environment, individuals' spiritual identity increases as their behavior and their God image match with increasing accuracy the attributes of Deity. Conversely, conflicts between individuals' experiences and their God image will likely lead to either a decrease in the salience of their spiritual identity (detachment) or else a redefinition of their God image (differentiation).

Developmental progression over time. Each of the four psychological theories reviewed suggest that identity develops during the course of life beginning from birth, although the theories differ somewhat regarding when and how individuals attain a sense of self. As suggested from the spiritual parallels to each of the four theories, spiritual identity development may also involve a longitudinal process that initiates in early childhood. However, we propose that spiritual identity development may also commence or resume in adulthood during a "second birth" (John $3: 3-4)$. Thus we can follow the course of spiritual identity development from an infant's birth and/or from an adult's rebirth.

Moreover, we propose that unlike certain aspects of psychological development (e.g., cognitive or social), spiritual identity development does not necessarily proceed in linear fashion after basic psychological skills have been acquired in childhood. Although our model may indeed fit a generally linear sequence of psychological development during early childhood (progression from the absence of a sense of self to the achievement of a sense of self that is integrated with the environment), we suggest that spiritual identity is more malleable than fundamental psychological processes. Therefore, after basic language, cognitive, and social skills have been obtained (usually by ages 7-8), spiritual identity development may undergo changes more accurately represented by a double spiral than a straight line. Support for this assertion comes from other theories specific to identity development, which recognize idiosyncratic development patterns such as returning to previous stages (McAdams, 1993, 1996; Steenbarger, 1991). For example, a person not ordinarily inclined to be spiritual might recognize and feel strongly the pres- 
ence of God during the months surrounding the birth of a child (Awakening), but then gradually become preoccupied with material concerns again (Preawareness) as continued spiritual prompts go unheeded. Or a child raised in an environment conducive to spirituality may by age seven already view her or himself as a child of God and have a relationship with God established through frequent prayer independent of parent supervision (Integration), but during adolescence have experiences that minimize the salience of spirituality (Pre-awareness) until a relationship with a youth pastor leads to questions about spiritual realities (Awakening) and further consideration of the individual's childhood spiritual experiences (Recognition). At this point, we hope to illustrate the developmental course of the spiritual self as suggested in our model by following the description of a spiritual rebirth recorded in the Bible.

\section{ILlustrating THE SPIRITUAL IDENTITY DEVELOPMENT MODEL:}

\section{The Case of the Prodigal Son}

The Prodigal Son is one of three parables recorded in chapter fifteen of the Gospel of St. Luke. In each of these three parables, Jesus likens the repentance of sinners to being "found." In the first two parables, the Parable of the Lost Sheep and the Parable of the Lost Piece of Silver, the "finding" is accomplished by an outside source: the owner of the sheep and the owner of the coin. In contrast, the Prodigal Son "came to" or "found" himself (Luke 15:17).

What does it mean that the Prodigal "came to himself"? Might it be that he remembered who he was, the son of a benevolent father? Perhaps he recalled experiences of his home, his father, his brother. Destitute and alone, the Prodigal recognized the constancy of his relationship to his father. He yearned to be reconciled, to reconnect to his father, and again experience the peace and joy of his boyhood home. The lost young man viewed himself as one who was perhaps unworthy to continue his status as son, unworthy of his earlier relationship with his father (Luke 15:21). It was, however, the realization of the continuity of his relationship with his father that allowed the Prodigal to arise and go home (Luke 15:20).

As we consider the meaning of this parable, the reconciliation of a sinner to God, we may begin to understand the process of spiritual identity development. The Prodigal represents those who at times feel lost in the world and disconnected from God. He may symbolize all of us. A parallel process to the Prodigal remembering his father, recognizing his continuing relationship with his father, and subsequently reconciling with his father may occur with us, as prodigals, and our Heavenly Father. Like the Prodigal, we may recall experiences of feeling close to our Father and understanding our purpose in the world. These memories of spiritual experiences enable us to recognize our continuing relationship with God and our constancy as eternal beings. Our spiritual identity is developed or recognized as we organize spiritual memories into spiritual self-stories. This process is supported by research linking identity development and memory (Conway \& PleydellPearce, 2000; Howe \& Courage, 1997).

These memories from which individuals derive their spiritual identities may be created through the processes suggested in this review. Such means of creating spiritual memories may include interacting with God and other children of God, learning religious teachings, and having other spiritual experiences. A sense of spiritual identity may be achieved by remembering and reflecting upon these spiritual interactions, teachings, and experiences through the process suggested in our tentative model: Pre-awareness of spiritual identity, Awakening of spiritual awareness, Recognition and reconstruction of fragmented spiritual memories into consistent themes, and Integration of spiritual memories and experiences into a spiritual identity with concomitant changes in behavior. These proposed spiritual identity stages correspond to those suggested in other theories that describe stage sequences for types of identity that tend to emerge during adulthood (Fassinger \& Miller, 1996; Parham, 1989; Phinney, 1990; Troiden, 1989). They are similar to the type of development we suggest can be found in the emergence of spiritual identity during a period of rebirth.

The Pre-awareness stage can be represented with the Prodigal's journey away from his father. The Prodigal traveled to a "far country," suggesting a deliberate attempt to separate himself from and forget his father. A similar process may occur with prodigals estranging themselves from a Heavenly Father. Such literal and symbolic distance, as well as worldly distraction (e.g., "riotous living"), may over time dim or erase memories of these relationships from a prodigal's awareness.

Like the Prodigal, those estranged from God may have experiences that promote reflection and recog- 
nition that they are "in want" (Luke 15:14). This spiritual desire prompted in the Awakening stage may stem from significant negative experiences or significant positive experiences. For the Prodigal, experiencing physical hunger prompted an acute awareness of his context and a re-assessment of his condition and identity. The desire to know and connect to God, or spiritual hunger, experienced by prodigals during particularly difficult life experiences may promote such an assessment and awareness of spiritual contexts previously unknown or forgotten. Just as positive life experiences, such as having a child, may increase recognition of one's own parents and home, positive spiritual experiences, such as feeling a sense of peace during a sermon, may increase awareness of one's heavenly home.

Reflecting on his current condition, the Prodigal recalled memories of his boyhood home, particularly memories of "bread enough to spare" (Luke 15:17) that could satisfy his hunger. Reflecting on the Heavenly Father, prodigals may recall memories of feeling closer to God and understanding more clearly their purpose in life. This stage of Recognition represents the process prodigals may experience as they remember positive spiritual experiences such as answered prayers, baptisms, or Sunday school lessons and as they begin to acknowledge similar spiritual experiences in their present circumstances.

As the Prodigal recalled and reflected upon memories of his father and home, he may have integrated such positive memories into a life narrative. Beyond the bread, the Prodigal perhaps recalled being deeply loved by his father. These memories may have allowed him to see that his father was a good, kind man who would accept him notwithstanding his perceived unworthiness. Although this integration most likely was not complete upon the Prodigal's return, as evidenced by his lament that he was no longer worthy to be called a son (Luke 15:21), his father dispelled that notion and provided ample evidence of his love for the wayward child. Similarly, the Integration stage involves the process prodigals may experience as they piece together spiritual memories and continue to have spiritual experiences that instill an identity as beloved sons and daughters of a Heavenly Father. Successful integration of these memories and experiences may allow prodigals to reconcile with God and to internalize the attributes they ascribe to Him. Ultimately, it is only through the grace of a loving Father that prodigals' false notions about Him and about themselves are dispelled, replaced with the peaceful assurance of being born of God (Luke 15: 24).

\section{Therapeutic Approaches to Promote Identity DeVelopment: Working WiTh THE SPIRITUAl SelF}

From a theistic perspective (Richards \& Bergin, 1997), psychotherapy involves assisting clients to recognize or reaffirm a spiritual identity. The model we propose has the potential to inform therapeutic approaches which promote spiritual identity development and, we believe, simultaneously promote psychological well-being. Specifically, therapists can use the model to first assess a client's current stage of spiritual identity development and then support him or her in progression to the next stage. This approach of matching therapeutic interventions with the stage of identity development coincides with other theories for promoting aspects of a client's identity (e.g., Parham, 1989; Walters \& Simoni, 1993). By first assessing and then intervening at the stage ascertained, therapists may be more likely to facilitate their clients' spiritual identity development.

\section{Pre-Awareness}

Clients at a Pre-awareness stage have limited recognition of spirituality. Some are even antagonistic to spiritual perspectives. With such clients, the therapist's primary goal would be to guide them toward opportunities to have a spiritual experience. Once they have had such an opportunity, the secondary goal is to implicitly or explicitly help the client recognize it as a spiritual experience.

Facilitating clients' spiritual experiences in and out of therapy is more beneficial and more appropriate than overtly discussing spirituality, which too often leads to detached cognitive analysis against which clients can easily defend. Rather than overtly mentioning religion or spirituality, therapists can seek to connect with their clients at a spiritual level, a practice which has been called "meta-empathy" (Richards \& Bergin, 1997). Such a "meta-empathic" connection is useful with clients at all stages of spiritual identity development, although it is particularly useful with clients at the Pre-awareness stage because the therapeutic relationship may be one of few opportunities to have a spiritual experience.

If the client acknowledges an event, interaction, or feeling that appears to be spiritual, the therapist can raise client awareness by implicitly or explicitly 
inviting the client to regard the experience as spiritual. For example, if a client expresses a feeling of contentment, the therapist could label implicitly by using a metaphor about inner balance or label explicitly by remarking that feelings of inner peace are sometimes spiritual. By labeling spiritual experiences, the therapist provides the client with a conceptual schema, while at the same time normalizing discussion of spiritual issues. If the client associates spirituality with prior negative religious experiences, labeling of new spiritual experiences provides a means to differentiate past injuries from positive spirituality. Similarly, labeling experiences provides clients with a lexicon of spiritual terms with which the therapist can facilitate further identity development.

\section{Awakening}

As with the case of the Prodigal, humility is often requisite for spiritual receptivity. Many clients seeking therapy are likely to be "in want" (Luke 15:14) and may have experienced or may be experiencing life events that encourage reflection on who they are and how they fit in the world. However, clients in the Awakening stage typically have minimal resources, understanding, or motivation to draw from to further their spiritual identity development, particularly if they focus exclusively on resolving their current dilemma or circumstance. Therefore, the primary goal for clients at this stage is to increase their trust in the availability and salience of spiritual guidance and strength.

The therapist can accomplish this goal by helping the client recognize and learn about spirituality, developing awareness of the benefits of relying on spiritual sources for strength. Clients who accurately recognize their own abilities and limitations are more likely to turn to spiritual sources for help. To increase insight, therapists can assist clients in retelling stories from a spiritual perspective and can ask questions, pose paradoxes, and use metaphors and analogies designed to help clients become aware of spiritual influences in their lives.

Because clients at the Awakening stage usually have limited experience with spirituality or may be motivated only by their current distress, stressing action plans may be premature. Rather, the therapist should focus on increasing his or her clients' faith in spiritual guidance, which may entail some actions but primarily emphasizes identification of spirituality across situations and relationships.

\section{Recognition}

Clients in the Recognition stage have already begun the cognitive and emotional process of generalizing spiritual awareness across situations and relationships. They have developed basic trust in the Holy Spirit who prompts them to reflect upon past experiences and strengthens them from time to time. Therefore, the primary goal when working with clients at this stage is to assist them to put their awareness into practice, helping them to better align their actions with their values and their God image.

Therapists can help clients prepare for behavioral change by exploring with them the ramifications of that change and by co-creating a vision of how that change would occur and what it would look like to the client. Meaningful prayer, fasting, and participation in ritual or public worship are particularly useful for clients at this stage as they begin internalizing an identity that includes spiritual experiences. Other useful actions include meditation on sacred texts, consultation with helpful clergy, and voluntary sacrifice of self for others. Encouraging clients to record spiritual memories and associated spiritual emotions such as peace, love, joy, and faith (Galations 5:22-23) in journals may be particularly helpful as writing enables them to sort out and identify consistent themes. Therapists can use these themes to help clients to see that spiritual experiences are part of their very nature. Thus work with clients at this stage should focus on internalizing spiritual experiences, helping the client view such experiences as a way of life.

\section{Integration}

Clients at an Integration stage already see themselves as spiritual beings, and they typically relate with others accordingly. However, their faith is stronger in some areas than in others. Although they strive to match their actions to their values, they may experience pride and selfish desires that limit their willingness to submit themselves to God's will. Therefore, the therapist's primary goal at this stage is to assist the client to come to know God, to establish an intimate relationship with Him.

As clients identify areas where their own desires could be made more congruent with their God image, they can be encouraged to trust that His grace is real, to make and keep spiritual commitments, to love and serve others, and to gradually surrender their own desires to God. Often these points are best achieved by assisting clients to restructure 
their environments to more closely match their God image. For example, clients may wish to reconsider the influence of the music/entertainment they listen to or the way they discipline their children.

Finally, clients at the Integration stage can be encouraged to elaborate upon their experiences by creating a coherent, meaningful spiritual self-story. Re-experiencing and re-creating this narrative explicitly may allow clients to see how they have become who they are through God's grace and how their identity is truly eternal, projecting into the future an endless relationship with God and His creations. According to Robertson (1990), this spiritual narrating process provides the very foundation of spiritual identity: "Storytelling may be a step towards wholeness and therefore a part of the healing activity of God. The Christian counselor will want to say, furthermore, that when one's story is told, identity and resolution found, God has been encountered in God's self-revelation" (p. 39).

\section{Points to Consider}

As noted earlier, therapists should not expect that clients' spiritual identity development will follow a linear progression through stages. They should also not expect clients to move from one stage to another rapidly. The best that a therapist can hope for is that a client will progress toward the next higher stage. Again, demonstrating sensitivity and support via "meta-empathy" may be the most helpful technique of all, whatever the client's idiosyncratic developmental patterns may be.

Most importantly, a therapist should remember that therapy is not an appropriate forum for proselytizing. They should be aware of how their own religious and spiritual beliefs influence their work in therapy and thus monitor potential imposition of their own values upon the client. Therapists can, however, be appropriately open with clients about spiritual issues, raising questions or making observations that are pertinent to the content of therapy and congruent with the client's interests and values. For a discussion of ethical guidelines for appropriately addressing spiritual issues in therapy, see Richards and Bergin (1997).

\section{Comparing the SPIRITUAL Identity DeVElopment ModelWith Fowler's FAith DeVelopment TheORY}

The spiritual identity development model proposed in this article may be compared with James
Fowler's (1981) work on faith development. Fowler proposed a developmental sequence for faith that also addressed some aspects of identity development. According to his model, identity is formed through a process of early interactions with others and subsequent individuation from others. Fowler posited that individuals must establish a secure sense of self through these processes before they are able to transcend the self and relate to God. His perspective contends that an individual must develop the Jamesian "social self" before developing the Jamesian "spiritual self." Fowler described individuals at Stage 3 of the faith development sequence as wanting to relate to a God who confirms the identity they have already attained through their social relationships. Others have observed that Fowler's theory presents two distinct and sequential processes of development: an identity development process of becoming more autonomous and individuated (faith stages 1 through 4) and a spiritual development process of transcending the self to relate to God (faith stages 5 and 6; Ford-Grabowsky, 1986). Our model argues that individuals develop a sense of spiritual self through a process of relating to God that is concurrent with and connected to the process of relating to others. Rather than asserting the need to separate from others in order to transcend the self and relate to God, our model suggests that individuals need to connect to others and to God in order to transcend the self.

Fowler further focuses on cognitive changes within the individual (e.g., changes from concrete to abstract thinking, changes from egocentrism to perspective-taking) to explain progression through levels of identity and faith. From the perspective of our spiritual identity model, spiritual identity development is promoted primarily from divine influences outside the individual. Thus, rather than being an afterthought as with Fowler's (1981) theory, development through spiritual experiences becomes central in this new model.

\section{RESEARCH DIRECTIONS TO UNDERSTAND IDENTITY DEVELOPMENT:}

\section{Studying the Spiritual Self}

Our intent for this article was to examine possible parallels between spiritual identity development and major theories of psychological identity development, as well as to suggest possible therapy approaches derived from these theories that might 
be applied to promote healthy spiritual identity development. Although our analysis may provide useful insights into the construct of spiritual identity, this work represents a tentative conceptualization of spiritual identity that should be studied directly. We hope that the spiritual identity development and therapy models we have proposed provide an impetus for additional work and refinement.

This additional work might include an initial series of studies employing qualitative methods (e.g., interviews). Narrative approaches may be particularly useful for exploring how individuals experience the processes and changes in their spiritual identities (Ganzevoort, 1998b). Narrative methods would also allow researchers to assess contexts of and influences to spiritual development. Spiritual self-stories may reveal sequences of spiritual identity development to refine the stages we have proposed and to inform the question of whether the spiritual self develops after the social self, as proposed by Fowler, or concurrent with the social self, as presented in the proposed model. Furthermore, as Howard (1991) asserts, narrative research methods would facilitate communication and collaboration among researchers and participants of differing cultures, particularly of differing religious cultures.

Due to the intimate, even sacred nature of studying individuals' spiritual lives, researchers would do well to collaborate with religious leaders and religious scholars to more "truthfully" (Howard, 1985) represent the construct of spiritual identity. This dialogue between religious scholars and psychology scholars would be mutually beneficial in the study of such topics as the spiritual self (Jones, 1994).

As researchers gain additional insight into the construct of spiritual identity, further studies can be conducted to explore possible self-protective and self-enhancing effects of healthy spiritual identity development. These studies could examine possible links between stages of spiritual identity development and psychological well-being. Scholars have already proposed links between spiritual identity and coping capacity (Ganzevoort, 1998a). To examine such potential relationships, a quantitative measure based on the proposed spiritual identity development model would need to be created. Validation of the measure and the model could be informed by existing research on God image and spiritual attachment (e.g., Kirkpatrick, 1999). Further, therapy outcome studies could be conducted to monitor changes in psychological health subse- quent to therapy provided according to the spiritual identity therapy model.

In conclusion, individuals' developmental needs to define themselves and to connect to others are divine in origin (Josephson, 1994). Psychological theories may address but not entirely explain these needs (James, 1902); nevertheless, we can explore these shared human needs through secular theories interpreted through a theistic perspective without contradicting or adulterating religious belief. Therefore, as Christians and therapists we should continue to "feel after" (Acts 17:27) how individuals define and "find" themselves in relation to God and eternity by studying the spiritual self.

\section{REFERENCES}

Bergin, A. E. (1991). Values and religious issues in psychotherapy and mental health. American Psychologist, 46, 394-403.

Bjorck, J. P. (1995). A self-centered perspective on McIntosh's religious schema. The International Journal for the Psychology of Religion, 5, 23-29.

Bowen, M. (1978). Family therapy in clinical practice. Northvale, NJ: Jason Aronson.

Brandtstadter, J., \& Greve, W. (1994). The aging self: Stabilizing and protective processes. Developmental Review, 14, 52-80.

Conway, M. A., \& Pleydell-Pearce, C. W. (2000). The construction of autobiographical memories in the self-memory system. Psychological Review, 107, 261-288.

Coon, D. J. (2000). Salvaging the self in a world without soul: William James's The principles of psychology. History of Psychology, 3, 83-103.

Elkind, D. (1997). The origins of religion in the child. In B. Spilka \& D. N. McIntosh (Eds.), The psychology of religion: Theoretical approaches (pp. 97-104). Boulder, CO: Westview Press.

Erikson, E. H. (1996). The Galilean saying and the sense of "I." Psychoanalysis and Contemporary Thought, 19, 291-337.

Erikson, E. H. (1950). Childhood and society. New York: W. W. Norton \& Company.

Fassinger, R. E., \& Miller, B. A. (1996). Validation of an inclusive model of sexual minority identity formation on a sample of gay men. Journal of Homosexuality, 32, 53-78.

Ford-Grabowsky, M. (1986). What developmental phenomenon is Fowler studying? Journal of Psychology and Christianity, 5, 5-13.

Fowler, J. W. (1981). Stages of faith: The psychology of human development and the quest for meaning. New York: Harper \& Row.

Ganzevoort, R. R. (1998a). Religious coping reconsidered, part one: An integrated approach. Journal of Psychology and Theology, 26, 260-275.

Ganzevoort, R. R. (1998b). Religious coping reconsidered, part two: A narrative reformulation. Journal of Psychology and Theology, 26, 276-286. 
Hood, R. W. (1989). The relevance of theologies for religious experiencing. Journal of Psychology and Theology, 17, 336342 .

Howard, G. S. (1991) Culture tales: A narrative approach to thinking, cross-cultural psychology, and psychotherapy. American Psychologist, 46, 187-197.

Howard, G. S. (1985). The role of values in the science of psychology. American Psychologist, 40, 255-265.

Howe, M. L., \& Courage, M. L. (1997). The emergence and early development of autobiographical memory. Psychological Review, 104, 499-523.

James, W. (1968). The self. In C. Gordon \& K. J. Gergen (Eds.), The self in social interaction (Vol. 1, pp. 41-49). New York: J. Wiley \& Sons. (Original work published in 1910)

James, W. (1902). The varieties of religious experience: A study of human nature. New York: The Modern Library.

James, W. (1890). The principles of psychology: Vol. 1. New York: Henry Holt and Company.

Jones, S. L. (1994). A constructive relationship for religion with the science and profession of psychology: Perhaps the boldest model yet. American Psychologist, 49, 184-199.

Josephson, A. M. (1994). A clinical theology of developmental process: A child psychiatrist's perspective. Journal of Psychology and Theology, 22, 120-129.

Kegan, R. G. (1979). The evolving self: A process conception for ego psychology. The Counseling Psychologist, 8, 5-34.

Kelly, E. W. (1995). Religion and spirituality in counseling and psychotherapy. Alexandria, VA: American Counseling Association.

Kirkpatrick, L. A. (1999). Attachment and religious representations and behavior. In J. Cassidy \& P. R. Shaver (Eds.), Handbook of attachment: Theory, research, and clinical applications (pp. 803-822). New York: The Guilford Press.

Kohut, H. (1977). The restoration of the self. New York: International University Press.

Koteskey, R. L., Little, M. D., \& Matthews, M. V. (1991). Adolescent identity and depression. Journal of Psychology and Christianity, 10, 48-53.

Mahler, M. S., Pine, F., \& Bergman, A. (1975). The psychological birth of the buman infant: Symbiosis and individuation. New York, NY: Basic Books.

Markus, H. (1977). Self-schemata and processing information about the self. Journal of Personality and Social Psychology, 35, 63-78.

Markus, H., \& Nurius, P. (1986). Possible selves. American Psychologist, 41, 954-969.

McAdams, D. P. (1993). The stories we live by: Personal myths and the making of the self. New York: Morrow.

McAdams, D. P. (1996). Personality, modernity, and the storied self: A contemporary framework for studying persons. Psychological Inquiry, 7, 295-321.

Miller, G. (1999). The development of the spiritual focus in counseling and counselor education. Journal of Counseling and Development, 77, 498-501.
Miller, W. R., \& Martin, J. E. (Eds.). (1988). Behavior therapy and religion: Integrating spiritual and behavioral approaches to change. Newbury Park, CA: Sage.

Moreland, J. P. (1998). Restoring the substance to the soul of psychology. Journal of Psychology and Theology, 26, 29-43.

Parham, T. A. (1989). Cycles of psychological nigrescence. The Counseling Psychologist, 17, 187-226.

Phinney, J. S. (1990). Ethnic identity in adolescents and adults: Review of research. Psychological Bulletin, 108, 499-514.

Pulkkinen, L., \& Roenkae, A. (1994). Personal control over development, identity formation, and future orientation as components of life orientation: A developmental approach. Developmental Psychology, 30, 260-271.

Richards, P. S., \& Bergin, A. E. (1997). A spiritual strategy for counseling and psychotherapy. Washington, D.C.: American Psychological Association.

Richards, P. S., \& Potts, R. W. (1995). Using spiritual interventions in psychotherapy: Practices, successes, failures, and ethical concerns of Mormon psychotherapists. Professional Psychology: Research and Practice, 26, 163-170.

Richardson, R. W. (1987). "Differentiation of self" as a therapeutic goal for the systemic pastoral counselor. Journal of Pastoral Psychotherapy, 1, 33-45.

Rizzuto, A. (1979). The birth of the living God: A psychoanalytic study. Chicago: The University of Chicago Press.

Roberts, R. E., Phinney, J. S., Masse, L. C., Chen, Y. R., Roberts, C. R., \& Romero, A. (1999). The structure of ethnic identity of young adolescents from diverse ethnocultural groups. Journal of Early Adolescence, 19, 301-322.

Robertson, B. (1990). Storytelling in pastoral counseling: A narrative pastoral theology. Pastoral Psychology, 39, 33-45.

Sauvayre, P. (1995). On the dialectics of agency. Journal of Theoretical and Philosophical Psychology, 15, 144-160.

Schwartz, R. C. (1999). Releasing the soul: Psychotherapy as a spiritual practice. In F. Walsh (Ed.), Spiritual resources in family therapy (pp. 223-239). New York: Guilford Publications.

Shafranske, E. P. (Ed.). (1996). Religion and the clinical practice of psychology. Washington, D.C.: American Psychological Association.

Stark, R. (2000). Religious effects: In praise of "idealistic humbug." Review of Religious Research, 41, 289-310.

Steenbarger, B. N. (1991). All the world is not a stage: Emerging contextualist themes in counseling and development. Journal of Counseling and Development, 70, 288-296.

Troiden, R. R. (1989). The formation of homosexual identities. Journal of Homosexuality, 17, 43-73.

Walters, K. L., \& Simoni, J. M. (1993). Lesbian and gay male group identity attitudes and self-esteem: Implications for counseling. Journal of Counseling Psychology, 40, 94-99.

Worthington, E. L., Jr., Kurusu, T. A., McCullough, M. E., \& Sanders, S. J. (1996). Empirical research on religion and psychotherapeutic processes and outcomes: A ten-year review and research prospectus. Psychological Bulletin, 119, 448-487. 


\section{Authors}

POLL, JUSTIN B. Address: Department of Counseling Psychology and Special Education, Brigham Young University, 340 MCKB, Provo, UT 84602. Title: Counseling Psychology Doctoral Candidate. Degree: MA, Boston College. Specializations: Spirituality and positive psychology, vocational and consulting psychology, interpersonal and narrative psychotherapy, and qualitative research methodologies.

SMITH, TIMOTHY B. Address: Department of Counseling Psychology and Special Education, Brigham Young University, 340 MCKB, Provo, UT 84602. Title: Associate Professor. Degree: $\mathrm{PhD}$, Utah State University. Specializations: Spirituality and mental health, intergroup relations, multicultural psychology, and relational perspectives of mental health. 